\title{
Neoscytalidium dimidiatum causes canker and dieback on grapevine in Turkey
}

\author{
E. Oksal ${ }^{1}$ (D) $\cdot$ Y. Çelik ${ }^{2} \cdot$ G. Özer ${ }^{3}$
}

Received: 27 April 2019 / Accepted: 24 September 2019 / Published online: 25 October 2019

(C) Australasian Plant Pathology Society Inc. 2019

\begin{abstract}
In July 2018, a canker and dieback disease was observed with an incidence of up to $10 \%$ in five vineyards in Malatya province. The aim of this study was to characterise the causal organism by morphological and molecular characteristics. Based on macroand micro-morphological features of the colonies and sequencing of the $\beta$-tubulin gene, the translation elongation factor 1- $\alpha$ gene, the large subunit of rDNA gene, and the internal transcribed spacer region of rDNA, the pathogen was identified Neoscytalidium dimidiatum. Koch's postulates confirmed $N$. dimidiatum as a causal agent of symptoms associated with canker and dieback on grapevine plants in Turkey.
\end{abstract}

Keywords Vitis vinifera $\cdot$ Neoscytalidium dimidiatum $\cdot$ Canker $\cdot$ Dieback

Grapes (Vitis vinifera) are one of the world's most commonly produced fruit crops, with a global production of approximately 75 million tonnes in 2017 (FAOSTAT 2019). About 50\% of the annual production of grapes is used to make wine while one third is consumed as fresh fruit and the rest is dried. Turkey is the world's largest producer for dried grape with 429,000 t, constituting 28\% of global production in 2014 (FAO-OIV Focus 2016).

In July 2018, symptoms of trunk diseases on plants including diagnostic chlorotic foliage with necrotic margins, shoot blight and trunk cankers with internal wood necrosis were observed in vineyards in the Arapgir district of Malatya (Fig. 1a, b).

For fungal isolation, small pieces from necrotic woody tissues were surface sterilised with $1 \%$ sodium hypochlorite for $60 \mathrm{~s}$ and twice rinsed, air dried, and placed onto potato dextrose agar (PDA) amended with tetracycline $(0.01 \%)$. Petri dishes were incubated at $25{ }^{\circ} \mathrm{C}$ in the dark. After 3 to 5 days,

E. Oksal

oksalercin@gmail.com

1 Faculty of Agriculture, Department of Plant Protection, Malatya Turgut Ozal University, 44210 Malatya, Turkey

2 Arapgir District Directorate of Agriculture and Forestry, Republic of Turkey Ministry of Agriculture and Forestry, 44800 Malatya, Turkey

3 Faculty of Agriculture and Natural Sciences, Department of Plant Protection, Bolu Abant Izzet Baysal University, 14020 Bolu, Turkey isolates showed Neoscytalidium-like cultural and microscopic characteristics such as conidia formation as arthric chains from mycelia that were dark brown, thick-walled, 6.3 to $11.3 \times 2.3$ to $4.7 \mu \mathrm{m}(n=50)$, ovate to rectangular and observed to have 0- to 1-septate (Phillips et al. 2013) (Fig. 1c, d). The pure cultures were obtained by hyphal tips transferred to new plates.

To isolate DNA of a representative isolate designated as Arp2-D, DNeasy Blood and Tissue Kit (Qiagen, California, USA) was used following the manufacturer's protocol. The partial sequences of the $\beta$-tubulin gene (BT2), the translation elongation factor $1-\alpha$ gene $(E F 1-\alpha)$, the large subunit of rDNA (LSU) gene, and the internal transcribed spacer region (ITS) of rDNA of the isolate were employed to confirm the morphological identification (Phillips et al. 2013; Ray et al. 2010; Sakalidis et al. 2011). Target sequences of EF1- $\alpha$, BT2, LSU, and ITS were amplified using primers EF1-728 F and EF1-986R (Carbone and Kohn 1999), Bt2a and Bt2b (Glass and Donaldson 1995), LR0R and LR5 (Vilgalys and Hester 1990), and ITS5 and ITS4 (White et al. 1990), respectively. These loci were amplified using a $1100^{\mathrm{TM}}$ thermal cycler (BioRad, CA, USA) and subjected to bidirectional sequencing (Macrogen, Inc., Seoul, Korea). All DNA sequences of the isolate were deposited in GenBank with accessions: MK816354, MK816355, MK813853, and MK813852 for EF1- $\alpha$, BT2, LSU, and ITS, respectively. A BLASTn search of the resultant sequences showed $99.35-100 \%$ identity with $N$. dimidiatum CBS 145.78 strain sequences, which available in the GenBank database under the following accession numbers: EF1- $\alpha$ KF531795, BT2 
Fig. 1 Chlorotic foliage with necrotic margins caused by $N$. dimidiatum (a), branch of $\mathrm{cv}$. Köhnü plants showing necrosis in the center of the wood (b), hairy, dark brown colony of $N$. dimidiatum on PDA (c), conidia of $N$. dimidiatum. Bar $=$ $20 \mu \mathrm{m}(\mathbf{d})$

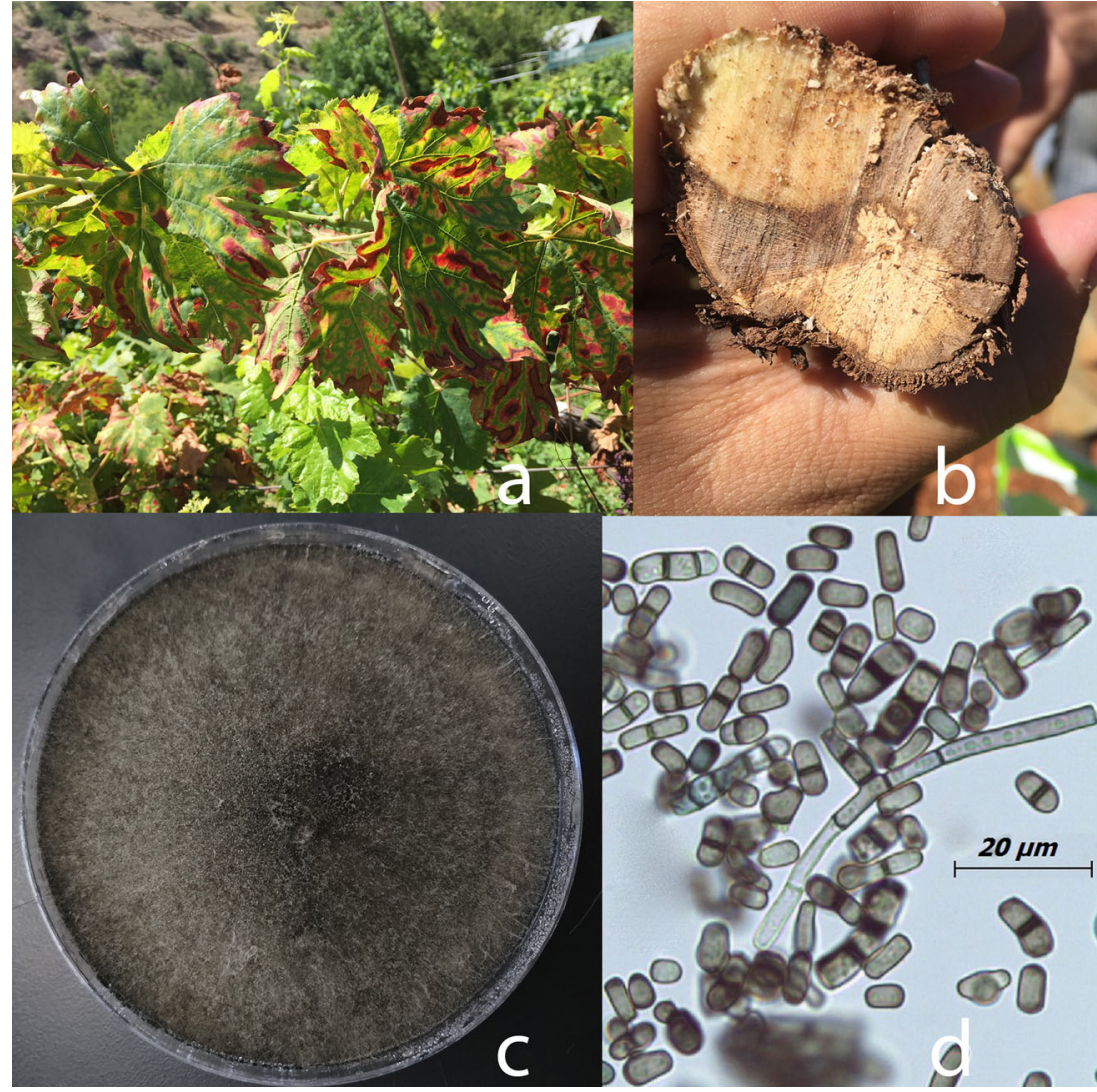

KF531796, LSU DQ377922, and ITS MH861121 with 299/ $299,456 / 459,1176 / 1176$, and 577/578 identical nucleotides, respectively.
A phylogenetic analysis where $E F 1-\alpha$ and ITS sequences obtained in this study were compared with those of $N$. dimidiatum isolates deposited in the GenBank and some
Fig. 2 Phylogeny of $N$.

dimidiatum and some species in Botryosphaeriaceae based on the combined ITS - EF1- $\alpha$ dataset

(Neighbor-joining). The bootstrap values (percentage, based on 1.000 replications) are shown on the branches

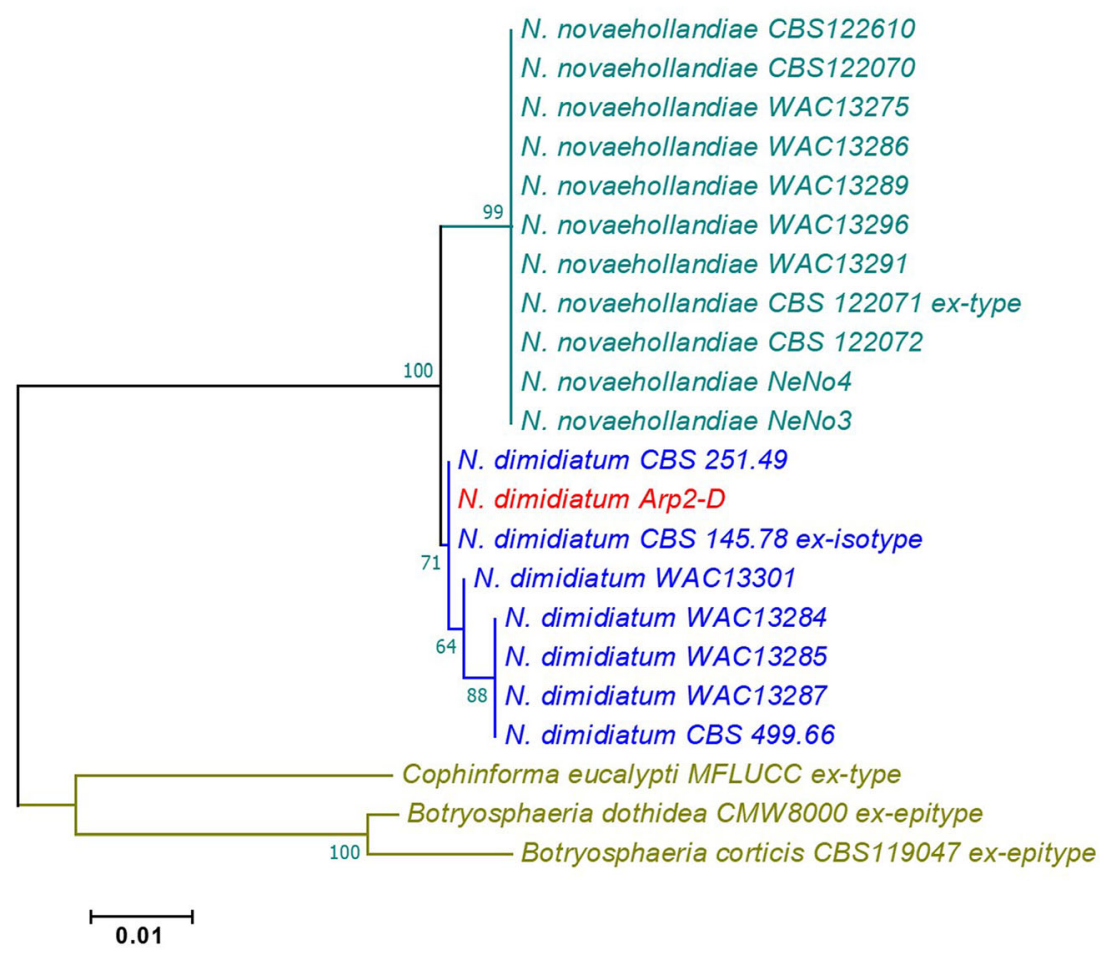


Botryosphaeriaceae species were added to the analysis (Fig. 2). Moreover, high similarities were also observed between the sequences of isolate Arp2-D and the sequences of some Turkish $N$. dimidiatum isolates (Kale4-C, ND94, ND121, ND159, ND180, etc.) obtained from different hosts and the isolates obtained from $V$. vinifera (E-238, CMM0314, CMM4579, UCR-Neo1, etc.) in USA and Brazil. Based on morphological and molecular identification, the isolates were identified as Neoscytalidium dimidiatum. The isolate Arp2-D was deposited in Erciyes University Culture Collection (EUCC - WDCM 1202) with the accession number EUCC$1911 \mathrm{M}$.

The pathogenicity test was conducted using $5-\mathrm{mm}-$ diameter mycelial plugs excised from ten-days-colonies. The plugs were applied into wounds of 2-year-old cuttings of $V$. vinifera $\mathrm{cv}$. Köhnü plants and the wound site containing the pathogen was sealed with moist filter paper and Parafilm. The control cuttings were inoculated with sterile agar plugs. Inoculated and control cuttings were maintained in a growth chamber at $25^{\circ} \mathrm{C}$ and high humidity for 21 days in a 12-h photoperiod. All inoculated cuttings showed typical symptoms of inner bark discoloration observed in vascular and cortex tissues. $N$. dimidiatum isolate Arp2-D caused lesions $31.6 \pm 6.8 \mathrm{~mm}$ on the cuttings excised from stems of cv. Köhnü plants. The pathogen was re-isolated from all inoculated cuttings and confirmed as described above, fulfilling Koch's postulates. No symptoms were observed in the control. The pathogenicity test was replicated twice on five replicated cuttings.

Neoscytalidium species cause canker and dieback diseases on several woody hosts of agronomic, forestry, and ornamental importance. $N$. dimidiatum has been identified as the causal agent of shoot blight and canker on grapevine in the USA (Rolshausen et al. 2013). N. dimidiatum has been reported as a destructive pathogen in Turkey such as causing blight of tomato (Türkölmez et al. 2019), canker, shoot blight, and root rot of pistachio (Derviș et al. 2019a), and black canker and root rot of walnut (Derviş et al. 2019b). To our knowledge, this is the first report of canker and dieback caused by $N$. dimidiatum on grapevine in Turkey.

\section{References}

Carbone I, Kohn LM (1999) A method for designing primer sets for speciation studies in filamentous ascomycetes. Mycologia 91:553556. https://doi.org/10.2307/3761358

Derviş S, Türkölmez Ş, Çifçi O, Ulubaş Serçe Ç, Dikilitas M (2019a) First report of Neoscytalidium dimidiatum causing canker, shoot blight and root rot of pistachio in Turkey. Plant Dis 103:1411. https://doi.org/10.1094/PDIS-01-19-0053-PDN

Derviș S, Türkölmez Ș, Çifçi O, Ulubaș Serçe Ç, Dikilitas M (2019b) First report of Neoscytalidium dimidiatum causing black canker and root rot of walnut in Turkey. Plant Dis (First Look). https://doi.org/ 10.1094/PDIS-02-19-0306-PDN

FAO-OIV Focus (2016) Table and dried grapes. http://www.fao.org/3/ai7042e.pdf. Accessed 27 April 2019

FAOSTAT D (2019). Food and agriculture organization of the United Nations. Statistical database. www.fao.org/faostat/en/\#data/QC. Accessed 27 April 2019

Glass NL, Donaldson GC (1995) Development of primer sets designed for use with the PCR to amplify conserved genes from filamentous ascomycetes. Appl Environ Microbiol 61:1323-1330

Phillips AJ, Alves A, Abdollahzadeh J, Slippers B, Wingfield MJ, Groenewald JZ, Crous PW (2013) The Botryosphaeriaceae: genera and species known from culture. Stud Mycol 76:51-167. https://doi. org/10.3114/sim0021

Ray JD, Burgess T, Lanoiselet VM (2010) First record of Neoscytalidium dimidiatum and $N$. novaehollandiae on Mangifera indica and N. dimidiatum on Ficus carica in Australia. Aust Plant Dis Notes 5:48-50. https://doi.org/10.1071/DN10018

Rolshausen PE, Akgül DS, Perez R, Eskalen A, Gispert C (2013) First report of wood canker caused by Neoscytalidium dimidiatum on grapevine in California. Plant Dis 97:1511. https://doi.org/10.1094/ PDIS-04-13-0451-PDN

Sakalidis ML, Ray JD, Lanoiselet V, Hardy GES, Burgess TI (2011) Pathogenic Botryosphaeriaceae associated with Mangifera indica in the Kimberley region of Western Australia. Eur J Plant Pathol 130:379-391. https://doi.org/10.1007/s10658-011-9760-z

Türkölmez Ș, Derviș S, Çifçi O, Ulubaș Serçe Ç, Dikilitas M (2019) New disease caused by Neoscytalidium dimidiatum devastates tomatoes (Solanum lycopersicum) in Turkey. Crop Prot 118:21-30. https:// doi.org/10.1016/j.cropro.2018.12.004

Vilgalys R, Hester M (1990) Rapid genetic identification and mapping of enzymatically amplified ribosomal DNA from several Cryptococcus species. J Bacteriol 172:4238-4246. https://doi.org/10.1128/jb.172. 8.4238-4246.1990

White TJ, Bruns T, Lee S, Taylor J (1990) Amplification and direct sequencing of fungal ribosomal RNA genes for phylogenetics. In: Innis MA, Gelfand DH, Sninsky JJ, White TJ (eds) PCR protocols, a guide to methods and applications. Academic Press, San Diego, pp 315-322 